\title{
WORDS, FORMS, AND PHRASES IN ESTONIAN FOLKSONGS AND HYMNS
}

\author{
Kristiina Ross, Ahti Lohk
}

\begin{abstract}
In the eighteenth century, songs of two essentially different types of culture were present in the repertory of the Estonian-speaking community: folksongs and hymns. The old tradition of folksongs (regilaul or runosong) representing the indigenous oral culture was still alive. At the same time, since the sixteenth century, more and more elements of European (Christian) written culture had penetrated into the mental world of Estonians. The structures of literary language (and thinking based on written texts in a broader sense) were transferred into Estonian mainly by means of translations of ecclesiastical literature. For certain socio-historical reasons, influences of literacy may have mainly reached Estonians through the translations of Lutheran hymns, which became especially popular in the eighteenth century. This was the century in which structures of indigenous oral culture and those of European written culture probably still functioned in the mental world of Estonians separately from each other. Only in the nineteenth century the two sets fused into literary Estonian, and the modern Estonian culture was born. In order to understand the mechanics of the genesis of modern Estonian, the present article juxtaposes the sublanguages representing the situation in the eighteenth century (prior to the fusion). The text-corpora of folksongs and Lutheran hymn translations are analysed on lexical, morphological, and morphosyntactical levels.
\end{abstract}

Keywords: grammatical phrases, language history, lexis, Lutheran hymns, morphological categories, runosong, written versus oral culture, word frequency

\section{JUXTAPOSED SUBLANGUAGES AND TEXT CORPORA}

The aim of the following juxtaposition is to explain the structure and mutual relations between two eighteenth century sublanguages of Estonian: the sublanguage of folksongs representing the indigenous oral culture, and the sublanguage of Lutheran hymn translations representing the written ecclesiastical culture. Both variants were poetic languages, many features of which relied on the metrical and poetic system in which they functioned. However, in the present paper prosody and strictly poetic circumstances will be disregarded and both sublanguages will be analysed first and foremost from the lexical and 
grammatical points of view as the media of the indigenous and the borrowed type of culture respectively.

In the history of the Estonian language the opposition of orality and literacy in the sense of Walter J. Ong (1988 [1982]) has been remarkably sharp. In the period of the genesis of literary Estonian (sixteenth to eighteenth centuries) the opposition was supported and intensified by the ethnic and linguistic confrontation of different social groups. Due to historical circumstances in the Late Middle Ages and the Early Modern Times, the Estonian-speaking community had no political, social or cultural élite. The indigenous Estonian culture developed only in oral form, practically untouched by any manifestations of literacy. Structures of written culture were transmitted into Estonian by Lutheran pastors of German origin, who started to translate catechisms, pericopes (i.e. sections of the New Testament required for the divine services of the liturgical year), hymns, and the Bible into Estonian. The first book including an Estonian ecclesiastical text was published in 1525 . The whole process culminated in 1739 , when the full Bible was translated and published by a group of Pietist clergymen. During the whole period and practically until the end of the eighteenth century, the Estonian-speaking community participated in the process of the development of written Estonian passively, at first as listeners (when German clergymen read the translated text aloud to them), and later on as readers. Only in the nineteenth century vernacular Estonians took over the standard Estonian language that the German clergymen had generated, and started to develop it themselves. The new modern Estonian culture which came into being in the nineteenth century can be regarded as a hybrid in which indigenous oral tradition and European literacy, transmitted into Estonian by German mediators, fused together. In order to better understand the mechanics of this fusion and the nature of the new hybrid culture and language, it would be expedient to study the previous period, when the two sublanguages representing both types of culture still functioned in the minds of Estonians separately. Thus, in the following an attempt will be made to model the linguistic situation of Estonian sublanguages in the eighteenth century.

The indigenous oral culture of Estonians is most artistically expressed in old folksongs. Certainly, it remains questionable how adequately the texts written down at the end of the nineteenth and at the beginning of the twentieth centuries actually reflect the oral Estonian language and the mental world of Estonians in the eighteenth century. In the present paper it is assumed that due to the conservative effect of metrical patterns the texts represent the former situation rather well. In the process of domesticating elements and structures of written culture into Estonian, the most important role was probably played 
by the seventeenth and eighteenth century translations of Lutheran hymns. The language of these translations can be regarded as a specific sublanguage of ecclesiastical Estonian, which had a stronger influence on the attitude of the Estonian-speaking community towards literary Estonian than the sublanguages of the translations of catechisms, periscopes, and the Bible. Due to the particular position of hymnal texts on the scale from orality towards literacy, they were easier to understand and to master for the semi-illiterate Estonian community than translations of pericopes or the Bible (Ross 2016).

Thus in the following the sublanguage of old folksongs representing indigenous oral Estonian culture and the sublanguage of the eighteenth century hymn translations representing the written Christian culture transmitted into Estonian by German clergymen will be juxtaposed.

The variant of standard Estonian, which was established in 1739 by the Pietist Bible translation, relied mainly on the Central dialect (Saareste 1940: 61-64; Kask 1984: 90-95). In Pietist hymn translations the same dialectal variant was used. In order to enable the present juxtaposition to bring forth, first and foremost, linguistic differences, which are due to different types of culture, and to ignore dialectal differences as much as possible, in the corpus of folksongs also only those texts have been selected, which were written down in the area where the Central dialect was spoken. The corpus of folksongs is formed by the texts of the Anthology of Estonian Folksongs (ERLA), but includes only texts that were written down in the parishes of the kernel area and the north-western district of the Central dialect (according to the division of Pajusalu et al. 2002: 57), including 20 parishes of the districts of Harjumaa and Järvamaa counties and the two parishes of Virumaa County (Väike-Maarja, Simuna), where the Central dialect was spoken. As for the thematic division, nursery songs and incantations as distinct types of text are excluded. The resultant corpus comprises 1178 songs, which include in total 53,223 running words.

The corpus of hymns is built up of the texts printed in one of the early editions of the Pietist hymnal (Hymns 1727 [1721]). It comprises 254 songs, which include in total 54,519 running words.

All the running words of the corpora were semi-automatically lemmatized (i.e. grouped under relevant headwords) and analysed from the point of view of parts of speech and morphological categories. For these actions a web-based software application was used, developed at the Institute of the Estonian Language. This special software was initially created only for old Estonian Bible translations. In order to use this software, folksongs as well as hymns were transformed into XML-format and imported into the database of the software. In determining the shape of the headwords, the principles worked out by the 
research group of the Old Written Estonian of the University of Tartu (see, e.g., Habicht et al. 2000: 21-23) were mainly followed. Headwords are given in a shape that corresponds to the morphophonological rules of present-day standard Estonian. Words of common etymology with a different phonetical shape are given under the same headword (e.g. kehran and kedrand are both given under the headword ketrama 'to spin'). Words with an etymologically common stem but different suffixes have got different headwords (e.g. kummuli 'upside down' and kumuliste 'upside down' are given under the headwords kummuli and kummulisti respectively). In the course of a morphological analysis every running word was labelled according to its part of speech and morphological form. The analysis was based on the morphological system of modern Estonian; word forms which do not match the present system (e.g. forms of the instructive case such as tulitse silmi 'with burning eyes', etc.), were in most cases left unlabelled. From amongst the specific categories of folksongs (Peegel 2006) only forms of the potential mood and the $k s e$-present were labelled. Sequences of different stems were regarded as compounds only if they were written as one word. Components of compounds were labelled separately, but in the statistics of the present paper compounds are regarded as undivided units.

\section{LINGUISTIC JUXTAPOSITION}

\section{Headwords and frequency lists}

The corpus of folksongs can be lexically described by 6,658 headwords (on average one headword for every 8 running words); the corpus of hymns can be lexically described by mere 1,828 headwords (on average one headword for every 29.8 running words). Taking into account that the amount of running words in the two corpora (53,223 and 54,519 respectively) is more or less balanced, the difference in the number of headwords is remarkable. There are probably several reasons for such discrepancy, some of them formal, others substantial (see Discussion).

The very top segments of the frequency lists of different sublanguages often tend to be quite similar (cf., e.g., Kaalep \& Muischnek 2002: 154). In the present case, however, significant differences can be noted already in the juxtaposition of the ten most frequent headwords of both sublanguages. 
Table 1. The 10 most frequent words of folksongs and hymns (in the order of frequency).

\begin{tabular}{|l|c|l|c|}
\hline \multicolumn{2}{|c|}{ Folksongs } & \multicolumn{2}{c|}{ Hymns } \\
\hline Word & $\begin{array}{c}\text { Number of } \\
\text { occurrences }\end{array}$ & Word & $\begin{array}{c}\text { Number of } \\
\text { occurrences }\end{array}$ \\
\hline mina 'I' & 1795 & sina 'you (sing.)' & 3019 \\
\hline olema 'to be' & 1560 & mina 'I' & 3014 \\
\hline ei 'no, not' & 660 & olema 'to be' & 1900 \\
\hline minema 'to go' & 529 & see 'this' & 1195 \\
\hline saama 'to get' & 526 & et 'that, since' & 1004 \\
\hline see 'this' & 522 & kui 'when, if' & 952 \\
\hline meie 'we' & 456 & meie 'we' & 937 \\
\hline tulema 'to come' & 440 & ja 'and' & 928 \\
\hline sina 'you (sing.) & 418 & ning 'and' & 832 \\
\hline kui 'when, if' & 412 & ei 'no, not' & 769 \\
\hline
\end{tabular}

As can be seen, 7 words out of 10 in both lists indeed coincide, but on the other hand the three specific words of either list are quite telling. All the specific words of the folksongs' top ten are verbs: minema, saama, tulema. In hymns all verbs except olema 'to be' stand further down the top ten list. All the specific words of the hymns' top ten are conjunctions: et, ja, ning. (Of these three in folksongs $j a$ is present in the second top ten, et stands in the 43rd position and ning (synonym of $j a$ ) does not occur in folksongs at all.) Yet another remarkable circumstance can be pointed out in connection with the personal pronouns mina and sina. ${ }^{1}$ In the sublanguage of hymns both belong to the absolute top, whereas the number of occurrences of one and the other is almost equal. In folksongs sina stands only in the 9th position, whereas its absolute number of occurrences is about four times smaller than the number of occurrences of mina.

A telling overview about the differences of the worlds of folksongs and hymns can be driven from the juxtaposition of the 30 most frequent autosemantic nouns and adjectives of either sublanguage (Table 2).

In the two lists only 3 words coincide: isa, käsi, and suur, whereas the meaning of the first actually differs in both sublanguages: in folksongs the word denotes family relations, in hymns it signifies God. The other 27 most frequent nouns and adjectives are specific in both sublanguages, representing the thematic domain of the respective songs. 
Table 2. The 30 most frequent nouns in folksongs and hymns.

\begin{tabular}{|c|c|c|c|}
\hline \multicolumn{2}{|c|}{ Folksongs } & \multicolumn{2}{|c|}{ Hymns } \\
\hline Word & $\begin{array}{c}\text { Number of } \\
\text { occurrences }\end{array}$ & Word & $\begin{array}{c}\text { Number of } \\
\text { occurrences }\end{array}$ \\
\hline mees 'man' & 306 & jumal 'God' & 588 \\
\hline kodu 'home' & 232 & Jeesus 'Jesus' & 577 \\
\hline $\begin{array}{l}\text { vend 'brother, boy- } \\
\text { friend' }\end{array}$ & 204 & $\begin{array}{l}\text { arm 'grace, mercy, } \\
\text { love' }\end{array}$ & 468 \\
\hline naine 'woman' & 200 & süda 'heart' & 438 \\
\hline pea 'head' & 181 & patt 'sin' & 396 \\
\hline noor 'young' & 176 & taevas 'heaven' & 334 \\
\hline tuba 'room' & 165 & surm 'death' & 269 \\
\hline hobune 'horse' & 160 & meel 'mind' & 259 \\
\hline poiss ‘boy' & 156 & häda 'trouble' & 255 \\
\hline neid 'girl' & 154 & hing 'soul' & 227 \\
\hline lai 'broad' & 150 & suur 'big' & 227 \\
\hline vaene 'poor' & 139 & hea 'good' & 218 \\
\hline $\begin{array}{l}\text { eit 'mother, old } \\
\text { woman' }\end{array}$ & 138 & ilm 'world' & 218 \\
\hline härg 'ox' & 136 & isa 'Father' & 218 \\
\hline väli 'field' & 132 & püha 'holy' & 208 \\
\hline küla 'village' & 130 & issand 'Lord' & 205 \\
\hline laps 'child' & 122 & vaim 'spirit' & 204 \\
\hline kiik 'swing' & 115 & elu 'life' & 201 \\
\hline suur 'big' & 115 & rõõm 'joy' & 201 \\
\hline maa 'land, earth' & 114 & armas 'lovely' & 197 \\
\hline hell 'tender' & 112 & kuri 'evil' & 196 \\
\hline käsi 'hand' & 111 & au 'honour' & 191 \\
\hline vana 'old' & 110 & $a b i$ 'help' & 158 \\
\hline pikk 'long' & 109 & sõna 'word' & 145 \\
\hline $\begin{array}{l}\text { hall 'grey; grey } \\
\text { horse' }\end{array}$ & 107 & vaev 'trouble' & 141 \\
\hline isa 'father' & 106 & käsi 'hand' & 139 \\
\hline päev 'day, sun’ & 103 & usk 'belief' & 139 \\
\hline kuld 'gold' & 98 & vägi 'power' & 137 \\
\hline ô 'yard' & 98 & kallis 'dear' & 125 \\
\hline ots 'end, top' & 97 & oige 'right' & 115 \\
\hline
\end{tabular}


The actors of folksongs are family members and villagers in the neighbourhood (mother, father, child, brother, boyfriend, man, woman, girl, boy). It is noteworthy that among the most important actors of folksongs there are two animals: horse (represented by two words, hobune and hall) and ox (härg). The place of action is the home of the singer, the village, and its neighbourhood (kodu 'home', tuba 'room', kiik 'swing', küla 'village', väli 'field', ouu 'yard'). Among the most important nouns, two words signifying parts of the body (käsi 'hand', pea 'head'), two words connected with location ( $m a a$ 'land earth', ots 'end'), and one word signifying time ( $p \ddot{a} e v$ 'day') are recorded. There are seven adjectives in the list or at least words that can function as adjectives, although some of them can function as substantives as well (e.g. hall '(adjective) grey; (substantive) grey horse'; the genitive form kulla of the noun kuld 'gold' can function as an inclinable adjective meaning 'dear').

In hymns the most frequent actors are represented by six nouns: jumal 'God', Jeesus 'Jesus', isa 'Father', issand 'Lord', vaim 'spirit', hing 'soul'. Considering that the first four of the listed nouns signify God and the fifth often also marks one of the persons of the Trinity (although it can occur in the phrase kuri vaim 'evil spirit' as well), the scope of actors in hymns is quite narrow. The place of action is either heaven or its abstract opposite world. The monotonousness of actors and locations in hymns is compensated by an abundance of abstract nouns meaning 'help', 'love', 'honour', ‘joy', 'trouble', 'life', 'death', 'sin', 'belief'. Among the rest of the substantives two refer to the domicile of man's belief (süda 'heart', meel 'mind'), two most often signify the acting power of God (käsi 'hand', vägi 'power'), one the Word of God (sõna 'word'). The number of possible adjectives is seven (although kuri 'evil' can be used both as an adjective or a substantive).

As we can see, the world of folksongs is filled by diverse familiar actors operating in their everyday environment. Hymns, on the other hand, are totally occupied by God and abstract categories related to him. At the same time the most frequent substantives of hymns tend to be related to the opposition of good and evil ('God', Jesus, 'love', 'heaven', etc. belong distinctively to the side of good, whereas 'world', 'trouble', 'death' and 'sin' belong to the side of evil). The most frequent substantives of folksongs cannot so obviously be associated with such an opposition. 


\section{Parts of speech}

The percentage of running words belonging to certain parts of speech in two sublanguages is distinctively different.

Table 3. Distribution of running words by parts of speech in folksongs and hymns.

\begin{tabular}{|c|c|c|c|c|}
\hline \multirow{2}{*}{$\begin{array}{l}\text { Part of } \\
\text { speech }\end{array}$} & \multicolumn{2}{|c|}{ Folksongs } & \multicolumn{2}{|c|}{ Hymns } \\
\hline & $\begin{array}{l}\text { Number of } \\
\text { running } \\
\text { words }\end{array}$ & Percentage & $\begin{array}{l}\text { Number of } \\
\text { running } \\
\text { words }\end{array}$ & Percentage \\
\hline Verbs & 12,892 & $23,6 \%$ & 12,969 & $23.8 \%$ \\
\hline Nouns $^{2}$ & 27,626 & $51.9 \%$ & 16,125 & $29.6 \%$ \\
\hline Pronouns & 4,998 & $9.4 \%$ & 12,047 & $22.1 \%$ \\
\hline Adverbs $^{3}$ & 4,385 & $8.0 \%$ & 5,460 & $10.0 \%$ \\
\hline Conjunctions & 1,269 & $2.4 \%$ & 4,165 & $7.6 \%$ \\
\hline Interjections & 234 & $0.4 \%$ & 798 & $1.5 \%$ \\
\hline Particles $^{4}$ & 1,438 & $3.8 \%$ & 2,517 & $4.6 \%$ \\
\hline Unlabelled & 256 & $0.5 \%$ & 438 & $0.8 \%$ \\
\hline In total & 53,223 & $100 \%$ & 54,519 & $100 \%$ \\
\hline
\end{tabular}

The percentage of verb forms in both corpora is almost equal. Even the percentage of finite and non-finite forms among verb forms is quite similar in both corpora (finite forms build 74.9\% of the total amount of verb forms in folksongs and $71.9 \%$ in hymns). This is somewhat unexpected considering the fact that, as Helle Metslang has stated (see Syntactic phrases), in the after-lines of folksongs it is the verb form that is most generally omitted (Metslang 1978: 162), and in lyrical songs even the headverse is often nominal (ibid.: 171).

As for the rest of the parts of speech, the two sublanguages differ significantly from each other. The percentage of nouns in folksongs is remarkably higher than in hymns ( $51.9 \%$ and $29.6 \%$ respectively). In the language of hymns, the percentage of pronouns, on the other hand, is significant as compared to the percentage of pronouns in folksongs ( $22.1 \%$ and $9.4 \%$ respectively). Apparent discrepancy is also evident in the percentages of conjunctions and interjections, both of which are much more common in the language of hymns than in folksongs. 


\section{Morphological categories}

The two sublanguages differ from each other as for the representation of morphological categories as well.

Among nominal categories the discrepancy is evident in the category of numerus. In the language of folksongs plural forms constitute $22.5 \%$ of all nominal forms, in the language of hymns the percentage of plural forms is only $6.0 \%$. As for the category of case, in the language of folksongs all the case forms of modern Estonian (except for the essive, i.e. nominative, genitive, partitive, illative, inessive, elative, allative, adessive, ablative, translative, terminative, abessive, and comitative cases) are represented in singular and plural. In the language of hymns, the same 13 cases are represented in singular, but in plural form only 9 cases are recorded (there were no plural forms of illative, ablative, terminative, or abessive cases).

Among verbal categories the discrepancy of two sublanguages is evident in mood, tempus, and voice.

Table 4. Distribution of finite word forms by different moods.

\begin{tabular}{|l|r|r|r|r|}
\hline \multirow{2}{*}{ Mood } & \multicolumn{2}{|c|}{ Folksongs } & \multicolumn{2}{c|}{ Hymns } \\
\cline { 2 - 5 } & $\begin{array}{l}\text { Number of } \\
\text { running } \\
\text { words }\end{array}$ & Percentage & $\begin{array}{l}\text { Number of } \\
\text { running } \\
\text { words }\end{array}$ & Percentage \\
\hline Indicative & 7,403 & $80.6 \%$ & 7,070 & $72,5 \%$ \\
\hline Imperative & 1,363 & $14.8 \%$ & 2,425 & $24.9 \%$ \\
\hline Conditional & 304 & $3.3 \%$ & 245 & $2.5 \%$ \\
\hline Potential & 76 & $0.8 \%$ & - & - \\
\hline Unlabelled & 42 & $0.5 \%$ & 7 & $0.1 \%$ \\
\hline Total & 9,188 & $100 \%$ & 9,747 & $100 \%$ \\
\hline
\end{tabular}

In folksongs, forms of the indicative constitute $80.6 \%$ of all finite verb forms, in hymns only somewhat more than $70 \%$. In the language of hymns, on the other hand, the imperative is considerably more frequent than in folksongs, constituting $24.9 \%$ of all finite forms, while in folksongs the percentage of the imperative is only $14.8 \%$. In folksongs an archaic morphological category, the potential mood, is represented, e.g. mina viinen 'maybe I take' (from the verb viima 'to take'). In ecclesiastical translations this morphological category was not used, except some rare forms of the verbs olema 'to be', andma 'to give' and saama 'to get' in certain versions of the Bible translation. In hymn translation no forms of the potential mood have been recorded. 
As for the category of tempus, the juxtaposition indicates that the language of folksongs uses significantly more past tense forms than the language of hymns. In folksongs, forms of the imperfect constitute $31 \%$ of all finite verb forms. In hymns the percentage of the imperfect is only $6.5 \%$.

The category of voice has two members in Estonian: personal and impersonal. In folksongs the marked member of the category, impersonal, is a bit more frequent than in the language of hymns. The percentage of impersonal forms in either language is $6.1 \%$ and $2.8 \%$ of all finite verb forms respectively.

\section{Syntactic phrases}

Great differences between the two corpora can easily be noted in the syntactic structure of respective sublanguages. Most of these differences, however, cannot be described in mere linguistic terms, as the syntactic structure of both sublanguages is tightly related to the way in which, in the respective poetic systems, lines are rhythmically structured, and especially to the way they are grouped into greater units. In old Estonian folksongs the basic unit is the line, which consists of eight syllables arranged into four trochaic metric feet following (more or less steadfastly) the rules of the archaic Kalevala metre (Laugaste 1974; Sarv 2008; Ross \& Lehiste 2001: 1-3). Folksongs have no strophic structure. Lines are grouped into longer units according to the principle of parallelism. Any group of parallel lines consists of one main line and one or several afterlines. The meaning of the action is established by the main line. In after-lines the meaning of the main line is expanded paradigmatically, after-lines are syntactically less complete and often elliptic. Syncretism, restricted lengths of the line, and communicative circumstances in which folksongs were performed did not allow to build long lines or sequences with a complicated structure. Thus even the syntactic structure of the main line is actually quite elementary. The main lines are composed by Estonian simple sentences with most common lengths and most elementary syntactic, semantic, and information structure. The surface structure of after-lines is identical to the structure of the main line or analogous to it. The analogy is obtained by an ellipsis of hierarchically higher elements (e.g. the predicate) or by the addition of hierarchically lower elements (e.g. the attribute). In brief, the structure of both the main and afterlines is simple and the number of possible varieties is limited (Metslang 1978: 162-166). Due to communicative circumstances, syntactic relations between successive groups of lines cannot be complicated either. Commonly the main lines of successive groups form a coordinated construction. Nevertheless, the most elementary types of subordination (e.g. kui/siis 'when if/then', seal/kus 'where/there', etc.) can also be used. In the present corpus 6,606 groups of lines 
have been distinguished, from which nearly one third $(2,087$ or $31.6 \%)$ are single lines. Most of the groups consist of two lines (2,208 groups or 33.4\%). Groups of three lines $(1,219)$ constitute $18.5 \%$, groups of four lines (627) constitute $9.5 \%$, groups of five lines (233) constitute 3.5\%, and groups of six or more lines (232 in total) also $3.5 \%$. In a typical group no conjunctions are used: syntactically coordinated lines, which from the semantic point of view are in paradigmatic relation with each other, are separated by commas, e.g.:
Panin kuuske kuivamaie, I put on the fir to dry, tamme jo tahenemaie, pajo-oksa pleekimaie. on the oak to season, on the willow-twig to bleach. (ERLA I: 211)

The analysed Estonian translations of Lutheran hymns metrically correspond to their German originals. In the translations the iambic or trochaic metre is observed even more strictly than in some of the originals. In hymns lines are organised in stanzas and strophes, which constitute syntactic entities in which the idea is in most cases syntagmatically developed from the first line to the last one. Lines and greater units can be in complicated syntactic relations with one another. The strophic structure of hymns varies significantly, e.g. Mahrenholz (1953: 249-259) distinguishes 126 different structures. In the present corpus of Estonian translations 2,033 strophes or stanzas including 2-10 lines are distinguished (besides 46 longer texts with no strophic division). Most typical are strophes consisting of 4 lines (358, which make up $17.6 \%$ of the total amount of strophes). From the semantic point of view lines are generally in syntagmatic relation to each other. In most cases at least some of the lines are syntactically subordinated to one another, which is expressed by subordinating conjunctions, e.g. (the translation of the last strophe of the hymn Nun danket all by Paul Gerhardt):
Kui meie südda löhki lääb,
If our heart will break up,
Meid panne hingama, put us to rest,
Et meie silm seäl Jesust nääb,
Kui läh'me maggama.
so that our eye can see Jesus there, when we fall asleep.

(Hymns 1727 [1721]: 237)

The principally different syntactic organisation of folksongs and hymns is reflected in the different percentage of conjunctions in both sublanguages. In the top ten of the frequency list of hymns four conjunctions are included, whereas in the top ten of folksongs there is only one. In hymns conjunctions constitute $7.7 \%$ of all running words, in folksongs a mere $2.4 \%$ (see subdivisions "Headwords and frequency lists" and "Parts of speech"). ${ }^{5}$ 
Nevertheless, there are syntactic differences between the two sublanguages, which do not result from the difference between the poetical systems, but can be described as purely linguistic ones. For example, obvious differences become apparent in expressing the actor in some non-finite constructions. In folksong constructions with infinitive and passive participles (both the present and the past one), the actor can be expressed by the genitive form. In the corpus, 57 phrases (in 55 lines) have been recorded where the genitive in construction with the infinitive expresses the actor, e.g. Maa alla madude ('worm' GPl) sü̈̈a ('to eat' Inf), ilma tõukude ('maggot' GPl) imeda ('to suck' Inf) 'Under the earth [to be] eaten by the worms, sucked by the maggots'. In constructions with participles such genitive forms are rarer in the folksongs. In the corpus, 15 phrases (in 13 groups of parallel lines) have been recorded with the past participle, e.g. Sirp on kurja sepa ('smith' GSg) tehtud ('to do' PtsPtPss) 'the reaping hook has been forged by a bad smith'. With the present participle only three phrases (in two groups of parallel lines) have been recorded, e.g. Mina põle pere ('family' GSg) peksetavaks (translative case of the passive present participle of the verb 'to beat') 'I am not to be beaten by the family'.

In the language of hymns non-finite constructions where the actor is expressed by the genitive are unknown. On the other hand, in constructions with the past participle the actor can be expressed by elative, e.g. Arm Jummalast on tootud 'Grace has been promised by God' (by analogy of the respective German construction vom Gott gelobt).

In modern Estonian amongst the described phrases only genitive forms with the past participle in construction with the auxiliary olema 'to be' are common (e.g. Luuletus on selle tüdruku kirjutatud 'the poem has been written by this girl'). On the basis of this construction the periphrastic passive has been developed. Other archaic genitive constructions typical of folksongs, and borrowed elative constructions typical of hymn translations are rare in modern Estonian and need a specific context (e.g. Tööjäi poisi teha 'the task was left to the boy'; See töö jäi minust lõpetamata 'the task remained unfinished from my side').

\section{DISCUSSION}

The juxtaposition indicates that the two analysed eighteenth century sublanguages of Estonian differ significantly from each other. Differences become apparent on all analysed levels: lexical, morphological, and morphosyntactical.

On the lexical level the most apparent difference lies in the amount of headwords of the two corpora, which may have several reasons. One of the formal reasons probably lies in the fact that the language of folksongs varies more 
freely and one and the same stem may be combined with several suffixes with a similar meaning, in which case the corresponding sequences are described by different headwords (e.g. laiali, laialisti 'scattered'). The language of hymns has been standardised and this kind of variation is very rare there. Another formal reason probably lies in compounds and the percentage of them in either corpus. As mentioned above, in the present statistics, compounds are regarded as undivided units and get separate headwords. As a result, e.g. the running word eluaea 'of lifetime' in folksongs needs a special headword eluaeg 'lifetime' (in addition to the usual headwords elu 'life' and aeg 'time'); the sequence of two words ello aial 'in lifetime' of hymns can be described by the existing headwords $e l u$ and $a e g$, and needs no special headword. At the same time the percentage of compounds in folksongs is remarkably higher than in hymns: in folksongs compounds make up $8.3 \%$ of all running words and $34.7 \%$ of headwords; in the language of hymns the respective numbers are $1.15 \%$ and $11.3 \%$. To some extent the difference between the number of headwords in either corpus is due to the thematic scope of the songs. The most frequent nouns of either corpus testify that folksongs and hymns both focus on their own narrow thematic domain; anyhow, folksongs seem to cover a much wider area than hymns. To some extent, nevertheless, the difference between the number of headwords reflects the lexical variety/monotonousness of either language: the language of folksongs is certainly lexically richer than the language of hymns.

The lists of the most frequent nouns of both sublanguages testify that the two types of songs represent completely different worlds. The language of folksongs reflects everyday life of common people in their familiar surroundings. The language of hymns describes man's relation to God and abstract categories by which this relation is determined.

The percentage of different parts of speech in both sublanguages is telling. Folksongs are rich in nouns. This corresponds to the structure of groups of parallel lines: in after-lines verb forms are often omitted, but the noun of the main line is replaced by other nouns. The language of folksongs is additive, rich in pictures and descriptions in which one and the same actor or undergoer is repeatedly depicted by different nouns. In hymns, on the other hand, conjunctions and pronouns with an abstract and relatively empty meaning make up a considerable part of running words.

As for morphological categories, many archaic categories are represented in old folksongs (Peegel 2006), which in the eighteenth century were probably already out of use in everyday communication. From amongst such categories in the present corpus, only the potential mood and the so-called $k s e$-present were labelled. Other archaic word forms were classified unlabelled, since it was quite obvious that the German clergymen were not able to make use of them 
in their translations. Among the categories represented in both sublanguages, significant differences can be noted concerning the percentage of one or another member of the same category. In the language of hymns significantly more imperative, present, and singular forms were recorded than in the language of folksongs. Together with the fact that the frequency of the pronouns mina ' $\mathrm{I}$ ' and sina 'you' was equally high in hymns and among the parts of speech interjections were remarkably numerous, the language of hymns can be described as more dialogical and emotional than that of folksongs. Hymns can be considered as dialogues between God and the believer. In folksongs the indicative, past tense, and plural prevail. In comparison to hymns, folksongs seem to be more narrative and epic, although generally the Estonian runosong is described as lyric poetry with few epic elements.

Differences in the syntactic structure of the two corpora are largely due to the poetic system of either type of songs. The syntactic relations of folksongs can be described as additive and coordinative, while hymns tend to be analytic and subordinative. Strictly linguistic features of morphosyntactic phrases of the language of folksongs can be described as archaic and indigenous, while specific syntactic constructions of hymns tend to be artificial and German-biased.

According to Walter Ong, orality and orally performed texts can be characterised as situational, immediate, natural, communal, formulaic, additive, and aggregative; literacy and written texts, on the other hand, as abstract, distanced, artificial, private (or even solipsistic), coherent, subordinative, and analytic (Ong 1988 [1982]: 26, 31-116). On the basis of these characteristics, in some aspects the sublanguages of folksongs and hymns can indeed be opposed as representatives of oral and written culture. The sublanguage of folksongs is more situational, natural, formulaic, additive, and aggregative; the sublanguage of hymns is more abstract, artificial, coherent, subordinative, and analytic. The juxtaposition of the eighteenth century sublanguage of hymns with the contemporary sublanguage of the Bible translation has shown (Ross 2016) that in some respects the language of hymns satisfies the criteria of literacy even better than the sublanguage of ecclesiastical prose: it is more abstract, artificial, and German-biased. On the other hand, the present juxtaposition shows that in some respects the sublanguage of hymns satisfies the criteria of orality even better than the sublanguage of folksongs: dialogical essence and emotional emphasis make hymns very immediate. As for the opposition of communality/privateness, the position of hymns is particularly ambiguous. Since hymns were congregational songs, their text was meant to be performed collectively even if the content of some of them is very private. As such, hymns were a suitable bridge which enabled the semi-literate Estonians to move from the old oral tradition and embrace the new literacy mediated by the Germans. 


\section{ACKNOWLEDGEMENTS}

The article was supported by personal research grant PUT550 from the Estonian Ministry of Education and Research and by the European Union through the European Regional Development Fund (Centre of Excellence in Estonian Studies).

\section{NOTES}

1 The headwords mina and sina cover also short forms of the respective pronouns ( $m a$, $m u$, etc. and $s a, s u$, etc.)

${ }^{2}$ In the present statistics the class of nouns includes substantives, adjectives, and numerals.

3 In the present statistics the class of adverbs includes both autosemantic adverbs and affixal adverbs.

${ }^{4}$ In the present statistics the class of particles includes pre- and postpositions, negational words of negative forms, bound morphemes, and bound stems and citation loans.

5 Partially the different percentage of conjunctions in both sublanguages can of course be explained with metrical circumstances: iambic metre favours monosyllabic unstressed conjunctions at the beginning of the line.

\section{BIBLIOGRAPHY}

ERLA = Eesti rahvalaulud: Antoloogia . Vols. I-IV, 1960-1974. [Estonian Folksongs: Anthology.] Ed. by Ülo Tedre. Tallinn: Eesti Raamat.

\section{REFERENCES}

Habicht, Külli \& Kingisepp, Valve-Liivi \& Pirso, Urve \& Prillop, Külli 2000. Georg Mülleri jutluste sõnastik. [Dictionary of the Sermons of Georg Müller.] Tartu Ülikooli eesti keele õppetooli toimetised 12. Tartu: Tartu Ülikool. Available at http://dspace.ut.ee/handle/10062/52423, last accessed on January 3, 2017.

Hymns 1727 [1721] = Eesti-Ma-Rahwa Laulo-Ramat, Mis sees Önsa Lutterusse ja muud teised wannad ning ued kaunid Laulud on üllespandud. [Hymnal for Estonian Country People.] Tallinn: Eestimaa Konsistooriumi kirjastuskassa. Available at http://www.digar.ee/arhiiv/et/raamatud/13552, last accessed on January 3, 2017.

Kaalep, Heiki-Jaan \& Muischnek, Kadri 2002. Eesti kirjakeele sagedussõnastik. [Frequency Dictionary of Literary Estonian.] Tartu: Tartu Ülikooli Kirjastus. 
Available at https://www.researchgate.net/publication/265815601_EESTI_ KIRJAKEELE_SAGEDUSSONASTIK, last accessed on January 3, 2017.

Kask, Arnold 1984. Eesti murded ja kirjakeel. [Estonian Dialects and Standard Estonian.] Eesti NSV Teaduste Akadeemia Emakeele Seltsi toimetised 16. Tallinn: Valgus. Available at http://dspace.ut.ee/handle/10062/29148, last accessed on January 3, 2017.

Laugaste, Eduard 1974. Regivärsilise rahvalaulu stiilist. [Stylistic Features of Estonian Regilaul.] In: Ülo Tedre (ed.) Eesti rahvalaulud: Antoloogia. [Estonian Folksongs: Anthology.] Vol. IV. Tallinn: Eesti Raamat, pp. 20-44.

Mahrenholz, Christhard 1953. Übersicht über den Strophenbau der Lieder. Handbuch zum Evangelischen Kirchengesangbuch. Herausgegeben von Christhard Mahrenholz und Oskar Söhngen unter Mitarbeit von Otto Schliszke. Band I. Erster Teil. Göttingen: Vandenhoeck \& Ruprecht, pp. 249-264.

Metslang, Helle 1978. Süntaktilisi aspekte eesti regilaulu värsiparallelismis. [Syntactic Aspects in Verse Parallelism of Estonian Runic Songs.] Diss. (PhD Thesis). Tartu University. Manuscript.

Ong, Walter J. 1988 [1982]. Orality and Literacy: The Technologizing of the Word. London \& New York: Methuen.

Pajusalu, Karl \& Hennoste, Tiit \& Niit, Ellen \& Päll, Peeter \& Viikberg, Jüri 2002. Eesti murded ja kohanimed. [Estonian Dialects and Place Names.] Tallinn: Eesti Keele Sihtasutus.

Peegel, Juhan 2006. Eesti vanade rahvalaulude keel. [The Language of Old Estonian Folksongs.] Tallinn: Eesti Keele Sihtasutus.

Ross, Jaan \& Lehiste, Ilse 2001. The Temporal Structure of Estonian Runic Songs. Berlin \& New York: Mouton de Gruyter.

Ross, Kristiina 2016. Kirikulaulu osast eesti keele kirjalikustumisel. [The Role of Lutheran Hymns in the Development of Estonian Literacy.] Raamat ja aeg / Libri et memoria, Vol. 4. Tallinn: Eesti Rahvusraamatukogu, pp. 41-54.

Saareste, Andrus 1940. Piibli keel ja rahvakeel. [Bible Language and Vernacular.] Piibli keelest: Kahesaja-aastast eestikeelset piiblit mälestades. Akadeemilise Emakeele Seltsi toimetised 44. Tartu: Akadeemiline Emakeele Selts, pp. 12-64.

Sarv, Mari 2008. Värsimõõt ja hõimutunded: kvantiteedireeglid eesti regilaulus. [Metre and Sense of Kinship: Rules of Quantity in the Estonian Regilaul.] Keel ja Kirjandus, No. 6, pp. 409-420. Available at http://www.digar.ee/arhiiv/et/ perioodika/35166, last accessed on January 3, 2017.

Kristiina Ross is lead research fellow at the Institute of the Estonian Language in Tallinn, Estonia. Her doctoral dissertation defended at the University of Tartu in 1984 was on Finnic morphonology (The Instructive Case in the Finnic Languages).

Kristiina.Ross@eki.ee

Ahti Lohk is a researcher at the Department of Software Science of the Tallinn University of Technology, Estonia. He has a PhD in Computer Science (global wordnet studies).

ahti.lohk@gmail.com 